\title{
Autochthonous starter effect on the microbiological, physicochemical and sensorial characteristics of Ibores goat's milk cheeses
}

\author{
José GONZALEZ ${ }^{\mathrm{a}}$, Matilde MAS ${ }^{\mathrm{a}}$, Rafael TABLA ${ }^{\mathrm{b}}$, Javier MORICHE ${ }^{\mathrm{b}}$, \\ Isidro ROA ${ }^{\mathrm{a}}$, José Emilio REBOLLO ${ }^{\mathrm{b}}$, Pilar CÁCERES ${ }^{\mathrm{c} *}$ \\ a Instituto Tecnológico Agroalimentario, Junta de Extremadura. Aptdo. 20107, Badajoz 06071, Spain \\ b Departamento de Bioquímica, Biología Molecular y Genética, Facultad de Ciencias, \\ Universidad de Extremadura, 06071 Badajoz, Spain \\ ${ }^{c}$ Departamento de Microbiología, Facultad de Ciencias, Universidad de Extremadura, \\ 06071 Badajoz, Spain
}

(Received 13 September 2002; accepted 23 January 2003)

\begin{abstract}
The effect of adding four Lactococcus lactis ssp. lactis autochthonous strains as single starters (A, B, C and D) on the microbiological, physicochemical and sensory characteristics of Ibores raw goat's milk cheese was investigated. Batches with a commercial starter (E) and with raw goat's milk without starter $(\mathrm{F})$ were also made as controls. At the first day of ripening, the $\mathrm{pH}$ values of cheeses manufactured with any type of starter were significantly lower than those made without starter. There were significant differences $(P<0.05)$ in $\mathrm{pH}$ between batches, although no clear relationship with the starter type appeared. No significant differences $(P<0.05)$ in values of total solids (TS) or $\mathrm{NaCl}$ content were found between any of the batches after $7 \mathrm{~d}$ of ripening. The levels of the nitrogen fractions SN/TN and TCASN/TN were significantly $(P<0.05)$ higher in cheeses without starter after 7 and $30 \mathrm{~d}$ of ripening, but no significant differences were found between batches made with different starters. The evolution of lactic acid bacteria counts during ripening were very similar for all batches. While the enterococci counts in all types of cheeses throughout ripening remained practically constant, in cheeses manufactured with the commercial starter they were significantly $(P<0.05)$ lower at any given stage of ripening than those of the remaining types of cheeses. In cheeses made with autochthonous starters, the levels of coliforms and coagulasepositive staphylococci were reduced earlier in ripening than in the $\mathrm{E}$ and $\mathrm{F}$ cheeses. The best scores in the overall sensorial characteristics were awarded cheeses manufactured with two of the autochthonous starters, although the differences were not significant $(P<0.05)$ relative to cheeses made without starter.
\end{abstract}

Goat milk cheese / autochthonous starter / ripening / sensorial quality

Résumé - Effet de levains autochtones sur les caractéristiques microbiologiques, physicochimiques et sensorielles de fromage Ibores au lait de chèvre cru. Nous avons examiné l'effet de quatre souches autochtones pures de Lactococcus lactis ssp. lactis (A, B, C et D), utilisées comme levains, sur les caractéristiques microbiologiques, physicochimiques et sensorielles de fromage Ibores au lait de chèvre cru. Ces fromages ont été comparés aux fromages élaborés avec un levain du commerce $(E)$ et à ceux fabriqués sans addition de levain $(\mathrm{F})$. En début d'affinage, le $\mathrm{pH}$ des fromages sans levain était significativement $(P<0,05)$ plus haut que celui des autres fromages.

* Correspondence and reprints

Tel.: 34-924289363; fax: 34-924289687; e-mail: pcaceres@unex.es 
Bien que les valeurs du $\mathrm{pH}$ entre essais fluctuaient significativement $(P<0,05)$, celles-ci n'ont pas été directement rattachées au type de levain. À partir de 7 jours d'affinage, les valeurs d'extrait sec et la teneur en sel des différents fromages n'étaient plus significativement différentes. Les niveaux des fractions azotées NS/NT et NPN/NT étaient significativement $(P<0,05)$ plus élevés dans les fromages sans levains après 7 et 30 jours d'affinage, mais en revanche, dans les fromages élaborés avec les différents levains ils n'étaient pas significativement différents. Dans tous les fromages, l'évolution du nombre des bactéries lactiques totales était similaire pendant l'affinage. Dans toutes les fabrications, les populations d'entérocoques restaient à des niveaux presque constants pendant l'affinage. Cependant, dans les essais réalisés avec le levain commercial le nombre d'entérocoques était significativement $(P<0,05)$ inférieur à celui des autres fromages quel que soit le stade d'affinage. Dans des fromages faits avec les levains autochtones les niveaux de coliformes et de staphylocoques à coagulase positive diminuaient plus tôt pendant l'affinage par rapport à ceux qui étaient fabriqués sans levain ou avec le levain commercial. Après évaluation de la qualité sensorielle globale des fromages affinés, les fromages fabriqués avec deux levains autochtones obtenaient les meilleures notes bien que ne présentant pas de différence significative $(P<0,05)$ avec ceux faits sans addition de levain.

Fromage au lait de chèvre / levain autochtone / affinage / qualité sensorielle

\section{INTRODUCTION}

Ibores cheese is a raw goat's milk cheese with the Spanish Appellation of Origin since 1997. Its microbiological and physicochemical characteristics, cheesemaking process and main lactic acid bacteria have been described elsewhere [12].

The Appellation of Origin demands good microbiological quality and relative uniformity in marketing the cheeses. However, the microbiological contents of the raw milk used in cheesemaking is usually highly variable. This may lead to such problems as early blowing due to coliforms and a lack of uniformity of the final product. Desiring to correct these problems, Ibores cheesemakers are starting to add nonspecific commercial starters without any special control. While this may solve the microbiological problems, it can lead to the gradual loss of wild strains involved in generating the cheese's particular properties. The same commercial starter is also being used to manufacture other types of cheeses [14] which could lead to final products that are scarcely distinguishable. It would hence be desirable to provide the cheesemakers with a starter with autochthonous lactic acid bacteria that will yield safer products while preserving the original Ibores cheese characteristics.
To this end, we have studied the genetic and technological properties of several isolates (unpublished data), with the purpose of selecting some of them for cheesemaking.

The aims of the present study were to assess the contribution of different autochthonous Lactococcus lactis strains used as starters to the microbiological, physicochemical and sensory properties of raw milk Ibores cheese.

\section{MATERIALS AND METHODS}

\subsection{Starter cultures}

The microorganims used as cheese starters in this work had previously been isolated from Ibores cheese [12]. After the technological and genetic characterization of 50 strains of Lactococcus lactis ssp. lactis (unpublished data), 4 of them were selected to be used as single starters (types $\mathrm{A}, \mathrm{B}, \mathrm{C}$ and D) based on their acidifying and proteolytic characteristics (Tab. I). The acid production, after $6 \mathrm{~h} 30^{\circ} \mathrm{C}$, was determined according to the IDF guideline [9] and the proteolytic activity was determined, by the $o$-phthaldialdehyde method [2], in MRS $30^{\circ} \mathrm{C}$ for $24 \mathrm{~h}$, expressing the results in L-glycine equivalent $\left(\mu \mathrm{mol} \cdot \mathrm{mL}^{-1}\right)$. The commercial starter EZAL MA-4001 
Table I. Acidifying and proteolytic activity of selected autochthonous strains.

\begin{tabular}{llcc}
\hline Starter & Strain & $\begin{array}{c}\text { Acidifying activity } \\
\% \text { lactic acid } \\
\text { after } 6 \mathrm{~h} \text { at } 30^{\circ} \mathrm{C}\end{array}$ & $\begin{array}{c}\text { Proteolytic activity } \\
\mu \mathrm{mol} \mathrm{L-glycine} \cdot \mathrm{mL}^{-1} \text { milk }\end{array}$ \\
\hline A & L. lactis ssp. lactis CCBA 201 & 0.19 & 0.65 \\
B & L. lactis ssp. lactis CCBA 208 & 0.20 & 0.60 \\
C & L. lactis ssp. lactis CCBA 311 & 0.15 & 0.78 \\
D & L. lactis ssp. lactis CCBA 334 & 0.19 & 0.89 \\
\hline
\end{tabular}

“artisanal” (type E) supplied by RhônePoulenc Química (Texel-Meyhall, Madrid, Spain), customarily employed by the Ibores cheesemakers, was used as a control. According to the manufacturer, this commercial starter consists of Lactococcus lactis ssp. lactis, Lactococcus lactis ssp. cremoris, Lactococcus lactis ssp. lactis biovar diacetylactis and Streptococcus thermophilus.

\subsection{Cheesemaking}

The experimental cheesemaking was performed in the pilot plant of the Instituto Tecnológico Agroalimentario of Extremadura, using raw goat's milk obtained from local herds. The cheeses were manufactured according to the experimental protocol shown in Figure 1.

The experimental design was four blocks of batches on different days, using a single raw milk for each block, as follows:

- the first and second blocks consisted of 4 batches made of raw milk with the addition of one of the autochthonous starters (A, B, C and D batches), one batch of raw milk with the addition of commercial starter (E batch), and 2 batches of raw milk without addition of starter ( $\mathrm{F}$ batch);

- the third and fourth blocks were performed in the same way as described for the first and second blocks with the difference that only one batch with raw milk without starter was made in each block.

Starters were inoculated at $1 \%$ (final concentration) of a coagulated skim milk culture.

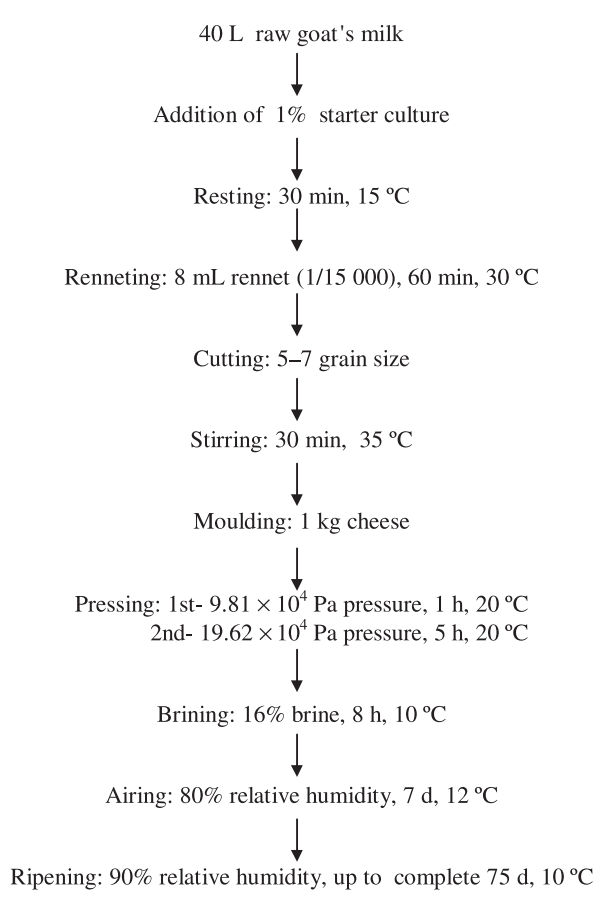

Figure 1. Flow diagram of the manufacturing procedure for experimental Ibores cheese.

\subsection{Microbiological and physico- chemical analyses}

For the microbiological analysis, samples of milk and of cheeses at 1, 7, 30, 60 and $75 \mathrm{~d}$ were taken from each batch. Representative aliquots of cheese $(10 \mathrm{~g})$ were homogenized with $90 \mathrm{~mL}$ of a sterile sodium citrate solution $(2 \% \mathrm{w} / \mathrm{v})$ at $45^{\circ} \mathrm{C}$ in a Stomacher 400 (Seward Medical, London, 
UK) for 2 min. Further decimal dilutions of both milk and the cheese homogenates in quarter-strength Ringer's solution were plated for the following microbial groups: lactic acid bacteria on MRS agar pH 5.7 (Merck, Darmstadt, Germany) incubated under anaerobiosis at $30^{\circ} \mathrm{C}$ for $72 \mathrm{~h}$; enterococci on Slanetz-Bartley agar (Merck) at $44{ }^{\circ} \mathrm{C}$ for $48 \mathrm{~h}$; coliforms in Violet Red Bile Agar (Merck) at $37^{\circ} \mathrm{C}$ for $24 \mathrm{~h}$; and coagulase positive staphylococci on BairdParker agar (Merck) at $37^{\circ} \mathrm{C}$ for $24-48 \mathrm{~h}$ and then confirmed by coagulase test (BioMérieux, Marcy-l'Étoile, France). All analyses were performed in duplicate.

For the physicochemical analysis, samples of the cheeses were taken at the same stages of ripening as for the microbiological sampling. Cheese $\mathrm{pH}$ was determined with a Crison 52-32 solid electrode (Crison Instruments S.A., Barcelona, Spain). Cheese total solids (TS) content was determined according to the IDF standard 4A [7]. The $\mathrm{NaCl}$ content was determined according to the IDF standard 88A [8] for cheeses. Total nitrogen (TN) was measured using the Kjeldahl method; soluble nitrogen at $\mathrm{pH} 4.6(\mathrm{SN})$ and soluble nitrogen in $12 \%$ trichloroacetic acid (TCASN) were determined according to Ardö [1] and then quantified using Kjeldahl. All analyses were performed in triplicate.

\subsection{Sensorial evaluation}

Cheeses were assessed organoleptically by a sensory panel of 12 judges trained in descriptive sensorial evaluation of cheeses, at $75 \mathrm{~d}$ of ripening. The qualities judged were: color, appearance, texture, intensity of aroma, quality of aroma, intensity of taste, quality of taste and general acceptance. The suitable texture attributes, detected as sensations in the mouth, for Ibores cheese are good solubility, medium elasticity and medium firmness, and considered as defects were crumbly or grainy textures. Samples were scored on a scale from 1 to 5 .

\subsection{Statistical analysis}

One-way analysis of variance of the physicochemical data on 1-, 7-, 30-, 60and 75-d-old cheeses, the microbiological data on milk and on 1-, 7-, 30-, 60- and 75-d-old cheeses, and the organoleptical data on 75-d-old cheeses were performed using the statistical software package SPSS version 10.0 for Windows (SPSS Inc., Chicago, USA). Statistical correlations between the 75-d-old physicochemical and sensorial values were analyzed by Pearson's correlation coefficient, using the same program.

\section{RESULTS AND DISCUSSION}

\subsection{Effect of the starters on the physicochemical characteristics during ripening}

Table II gives the results for the $\mathrm{pH}$, $\mathrm{NaCl}$ and total solids (TS) contents.

The $\mathrm{pH}$ values of all the cheeses made with starters were significantly lower $(P<0.05)$ than the $\mathrm{pH}$ of the cheeses made without starter at the initial stage of ripening. At 7, 30 and $75 \mathrm{~d}$ significant $(P<0.05)$ differences between batches were observed, but there was no clear relationship with the type of starter. The $\mathrm{pH}$ decreased in all cases up to day 30 of ripening, and thereafter increased, recovering at day 75 values very close to those observed on the first day.

The TS content values increased during ripening in all types of cheeses with no significant $(P<0.05)$ differences between batches from day 7 onwards. The $\mathrm{NaCl}$ content values increased with ripening time without significant differences between batches.

Table III gives the nitrogen fraction results. In all cases the SN/TN and TCASN/TN levels increased significantly with the age of the cheeses. The SN/TN content was significantly higher $(P<0.05)$ in cheeses made without starter than in the other batches from day 7 onwards. The TCASN/TN content was significantly higher $(P<0.05)$ in cheeses made without starter from day 30 onwards. 
Table II. Changes during ripening in $\mathrm{pH}$, total solids (TS) and $\mathrm{NaCl}$ content of Ibores cheeses made with different starters ${ }^{1}$.

Days of ripening

\begin{tabular}{|c|c|c|c|c|c|c|}
\hline Parameter & Starter $^{2}$ & 1 & 7 & 30 & 60 & 75 \\
\hline \multicolumn{7}{|l|}{$\mathrm{pH}$} \\
\hline & A & $5.04^{\mathrm{a}}$ & $4.82^{\mathrm{a}}$ & $4.76^{\mathrm{b}}$ & 4.78 & $4.93^{\mathrm{a}}$ \\
\hline & B & $5.03^{\mathrm{a}}$ & $4.90^{\mathrm{ab}}$ & $4.73^{b}$ & 4.75 & $5.13^{\mathrm{ab}}$ \\
\hline & $\mathrm{C}$ & $5.04^{\mathrm{a}}$ & $4.84^{\mathrm{a}}$ & $4.76^{b}$ & 4.82 & $5.01^{\mathrm{ab}}$ \\
\hline & $\mathrm{D}$ & $5.07^{\mathrm{ab}}$ & $4.94^{\mathrm{ab}}$ & $4.62^{\mathrm{a}}$ & 4.74 & $5.09^{a b}$ \\
\hline & $\mathrm{E}$ & $5.04^{\mathrm{a}}$ & $4.98^{\mathrm{b}}$ & $4.59^{\mathrm{a}}$ & 4.71 & $5.19^{\mathrm{b}}$ \\
\hline & $\mathrm{F}$ & $5.24^{b}$ & $4.97^{b}$ & $4.69^{\mathrm{ab}}$ & 4.72 & $5.22^{\mathrm{b}}$ \\
\hline
\end{tabular}

TS \%

$\begin{array}{llllll}\text { A } & 48.98^{\mathrm{ab}} & 52.83 & 57.78 & 59.15 & 67.03 \\ \text { B } & 50.99^{\mathrm{c}} & 52.43 & 56.87 & 60.23 & 63.59 \\ \mathrm{C} & 50.10^{\mathrm{bc}} & 51.64 & 56.29 & 61.89 & 66.52 \\ \mathrm{D} & 51.74^{\mathrm{c}} & 52.38 & 57.28 & 61.69 & 68.76 \\ \mathrm{E} & 50.52^{\mathrm{bc}} & 53.19 & 55.62 & 61.12 & 65.68 \\ \mathrm{~F} & 48.22^{\mathrm{a}} & 51.12 & 56.54 & 62.69 & 67.05\end{array}$

$\mathrm{NaCl} \%$

\begin{tabular}{llllll} 
A & 0.89 & 1.24 & 1.75 & 2.16 & 2.26 \\
B & 0.72 & 0.97 & 1.28 & 1.60 & 2.01 \\
C & 0.80 & 1.12 & 1.59 & 1.84 & 2.01 \\
D & 0.74 & 1.17 & 1.45 & 1.84 & 2.11 \\
E & 0.76 & 1.35 & 1.57 & 1.87 & 1.99 \\
F & 0.77 & 1.14 & 1.63 & 1.95 & 2.12 \\
\hline
\end{tabular}

${ }^{1}$ Mean values of four batches made with the A, B, C, D and E starters, or of six batches of the F cheeses. 2 A = Lactococcus lactis ssp. lactis CCBA 201; B = Lactococcus lactis ssp. lactis CCBA 208; C = Lactococcus lactis ssp. lactis CCBA 311; D = Lactococcus lactis ssp. lactis CCBA 334; E = commercial starter; $\mathrm{F}=$ without starter. $\mathrm{a}, \mathrm{b}$, c: means of the same column with different superscripts differ significantly $(P<0.05)$.

The increased levels of proteolysis in the SN/TN content observed in cheeses made without starter can be attributed to less competition with lactococci so that a greater variety of bacteria with higher peptidase activity could have developed.
This primary proteolysis could enhance the formation of larger peptides which could lead, after day 7 , in a secondary proteolysis, to a greater yield of small peptides and aminoacids reflected in the higher levels of TCASN/TN content. 
Table III. Changes during ripening of nitrogen fractions of Ibores cheeses made with different starters ${ }^{1}$.

\begin{tabular}{|c|c|c|c|c|c|c|}
\hline \multirow{2}{*}{ Parameter } & \multirow{2}{*}{ Starter $^{2}$} & \multicolumn{5}{|c|}{ Days of ripening } \\
\hline & & 1 & 7 & 30 & 60 & 75 \\
\hline \multicolumn{7}{|l|}{ TN \% } \\
\hline & A & $3.41^{\mathrm{b}}$ & $3.59^{\mathrm{b}}$ & $3.77^{\mathrm{b}}$ & $4.08^{c}$ & 4.36 \\
\hline & B & $2.83^{\mathrm{a}}$ & $3.06^{\mathrm{a}}$ & $3.44^{\mathrm{ab}}$ & $3.52^{\mathrm{ab}}$ & 3.92 \\
\hline & $\mathrm{C}$ & $3.23^{\mathrm{ab}}$ & $3.30^{\mathrm{ab}}$ & $3.57^{\mathrm{ab}}$ & $3.94^{\mathrm{bc}}$ & 4.00 \\
\hline & D & $3.03^{\mathrm{ab}}$ & $3.10^{\mathrm{a}}$ & $3.37^{\mathrm{ab}}$ & $3.66^{\mathrm{ab}}$ & 4.11 \\
\hline & E & $2.87^{\mathrm{a}}$ & $3.00^{\mathrm{a}}$ & $3.09^{\mathrm{a}}$ & $3.37^{\mathrm{a}}$ & 3.96 \\
\hline & $\mathrm{F}$ & $2.84^{\mathrm{a}}$ & $2.94^{\mathrm{a}}$ & $3.18^{\mathrm{a}}$ & $3.53^{\mathrm{ab}}$ & 4.18 \\
\hline
\end{tabular}

SN/TN \%

$\begin{array}{llllll}\text { A } & 9.71 & 12.30^{\mathrm{a}} & 17.68^{\mathrm{a}} & 20.04^{\mathrm{a}} & 20.50^{\mathrm{a}} \\ \text { B } & 9.49 & 11.67^{\mathrm{a}} & 16.35^{\mathrm{a}} & 20.05^{\mathrm{a}} & 20.86^{\mathrm{a}} \\ \text { C } & 10.15 & 13.40^{\mathrm{a}} & 17.40^{\mathrm{a}} & 20.62^{\mathrm{a}} & 22.94^{\mathrm{a}} \\ \text { D } & 8.73 & 12.90^{\mathrm{a}} & 16.07^{\mathrm{a}} & 19.75^{\mathrm{a}} & 20.90^{\mathrm{a}} \\ \text { E } & 8.96 & 13.15^{\mathrm{a}} & 16.70^{\mathrm{a}} & 21.28^{\mathrm{a}} & 22.33^{\mathrm{a}} \\ \text { F } & 13.02 & 18.25^{\mathrm{b}} & 24.93^{\mathrm{b}} & 31.46^{\mathrm{b}} & 33.41^{\mathrm{b}}\end{array}$

TCASN/TN \%

$\begin{array}{llllll}\text { A } & 3.85 & 4.84 & 7.41^{\mathrm{a}} & 10.89^{\mathrm{a}} & 11.29^{\mathrm{a}} \\ \text { B } & 3.29 & 5.02 & 7.50^{\mathrm{a}} & 12.27^{\mathrm{a}} & 13.79^{\mathrm{a}} \\ \mathrm{C} & 3.21 & 5.09 & 8.58^{\mathrm{a}} & 10.60^{\mathrm{a}} & 11.66^{\mathrm{a}} \\ \mathrm{D} & 3.10 & 4.59 & 7.36^{\mathrm{a}} & 9.76^{\mathrm{a}} & 12.65^{\mathrm{a}} \\ \mathrm{E} & 3.33 & 4.55 & 8.48^{\mathrm{a}} & 11.76^{\mathrm{a}} & 13.17^{\mathrm{a}} \\ \mathrm{F} & 2.83 & 6.57 & 12.77^{\mathrm{b}} & 17.37^{\mathrm{b}} & 19.82^{\mathrm{b}}\end{array}$

${ }^{1}$ Mean values of four batches made with the A, B, C, D and E starters, or six batches of the F cheeses.

${ }^{2} \mathrm{~A}=$ Lactococcus lactis ssp. lactis CCBA 201; B = Lactococcus lactis ssp. lactis CCBA 208; C = Lactococcus lactis ssp. lactis CCBA 311; D = Lactococcus lactis ssp. lactis $\mathrm{CCBA} 334 ; \mathrm{E}=$ commercial starter; $\mathrm{F}=$ without starter. $\mathrm{a}, \mathrm{b}, \mathrm{c}$ : means of the same column with different superscripts differ significantly $(P<0.05)$.

\subsection{Effect of the starters on micro- biological characteristics during ripening}

Table IV lists the means of the microbiological counts in the milk and cheeses during ripening.
The counts of lactic acid bacteria on MRS were significantly $(P<0.05)$ lower in milk from batches manufactured without starter. This is simply because the milk samples were taken $30 \mathrm{~min}$ after the addition of the starters to the raw milk. However, from the first day of cheese ripening 
Table IV. Changes in log cfu $\cdot \mathrm{g}^{-1}$ of microbial groups during ripening of Ibores cheeses made with different starters ${ }^{1}$.

\begin{tabular}{|c|c|c|c|c|c|c|c|}
\hline \multirow{2}{*}{ Parameter } & \multirow{2}{*}{ Starter $^{2}$} & \multirow{2}{*}{ Milk } & \multicolumn{5}{|c|}{ Days of ripening } \\
\hline & & & 1 & 7 & 30 & 60 & 75 \\
\hline \multirow{6}{*}{$\begin{array}{l}\text { Total lactic } \\
\text { acid bacteria }\end{array}$} & $\mathrm{A}$ & $6.38^{\mathrm{ab}}$ & 9.41 & 9.28 & 8.73 & 7.92 & 7.80 \\
\hline & B & $7.18^{\mathrm{ab}}$ & 9.20 & 9.34 & 8.93 & 7.88 & 7.73 \\
\hline & $\mathrm{C}$ & $7.49^{\mathrm{b}}$ & 9.39 & 8.80 & 8.46 & 8.00 & 7.94 \\
\hline & $\mathrm{D}$ & $6.89^{\mathrm{ab}}$ & 9.15 & 9.27 & 8.86 & 7.82 & 7.79 \\
\hline & $\mathrm{E}$ & $6.59^{\mathrm{ab}}$ & 9.40 & 9.59 & 8.88 & 8.01 & 7.93 \\
\hline & $\mathrm{F}$ & $5.81^{\mathrm{a}}$ & 9.03 & 9.38 & 8.86 & 8.16 & 8.05 \\
\hline \multirow[t]{6}{*}{ Enterococci } & A & $4.10^{\mathrm{b}}$ & $5.80^{\mathrm{b}}$ & $5.27^{\mathrm{ab}}$ & $5.56^{\mathrm{b}}$ & $5.49^{\mathrm{b}}$ & $5.02^{\mathrm{b}}$ \\
\hline & B & $4.38^{\mathrm{b}}$ & $5.49^{\mathrm{ab}}$ & $5.99^{\mathrm{b}}$ & $5.29^{b}$ & $4.95^{\mathrm{ab}}$ & $4.54^{\mathrm{ab}}$ \\
\hline & $\mathrm{C}$ & $5.09^{\mathrm{b}}$ & $6.07^{\mathrm{b}}$ & $5.94^{\mathrm{b}}$ & $5.65^{\mathrm{b}}$ & $5.69^{\mathrm{b}}$ & $5.21^{\mathrm{b}}$ \\
\hline & $\mathrm{D}$ & $4.39^{\mathrm{b}}$ & $6.18^{b}$ & $5.97^{\mathrm{b}}$ & $5.69^{\mathrm{b}}$ & $5.96^{\mathrm{b}}$ & $5.43^{\mathrm{b}}$ \\
\hline & $\mathrm{E}$ & $2.59^{\mathrm{a}}$ & $3.91^{\mathrm{a}}$ & $3.66^{\mathrm{a}}$ & $3.57^{\mathrm{a}}$ & $3.53^{\mathrm{a}}$ & $3.09^{\mathrm{a}}$ \\
\hline & F & $3.79^{\mathrm{ab}}$ & $6.46^{\mathrm{b}}$ & $6.27^{\mathrm{b}}$ & $6.44^{\mathrm{b}}$ & $6.26^{\mathrm{b}}$ & $5.51^{\mathrm{b}}$ \\
\hline \multirow[t]{6}{*}{ Coliforms } & $\mathrm{A}$ & $3.38^{\mathrm{ab}}$ & 4.72 & $1.44^{\mathrm{a}}$ & 0.33 & nd & nd \\
\hline & B & $3.99^{\mathrm{b}}$ & 5.61 & $3.68^{\mathrm{bc}}$ & 1.31 & nd & nd \\
\hline & $\mathrm{C}$ & $4.06^{\mathrm{b}}$ & 5.14 & $2.41^{\mathrm{ab}}$ & 0.69 & nd & nd \\
\hline & $\mathrm{D}$ & $3.70^{\mathrm{b}}$ & 5.33 & $3.95^{\mathrm{c}}$ & 0.57 & nd & nd \\
\hline & $\mathrm{E}$ & $2.30^{\mathrm{a}}$ & 5.40 & $3.84^{\mathrm{c}}$ & 1.49 & 0.46 & nd \\
\hline & F & $3.02^{\mathrm{ab}}$ & 6.02 & $4.66^{\mathrm{c}}$ & 1.56 & 0.88 & nd \\
\hline \multirow{6}{*}{$\begin{array}{l}\text { Coagulase } \\
\text { positive } \\
\text { staphylococci }\end{array}$} & A & $2.48^{\mathrm{ab}}$ & $2.56^{\mathrm{a}}$ & nd & nd & nd & nd \\
\hline & B & $3.21^{\mathrm{b}}$ & $4.38^{\mathrm{b}}$ & $3.75^{\mathrm{d}}$ & nd & nd & nd \\
\hline & $\mathrm{C}$ & $2.76^{\mathrm{ab}}$ & $2.95^{\mathrm{ab}}$ & $1.27^{\mathrm{abc}}$ & nd & nd & nd \\
\hline & $\mathrm{D}$ & $2.82^{\mathrm{ab}}$ & $3.57^{\mathrm{ab}}$ & $3.09^{\mathrm{cd}}$ & nd & nd & nd \\
\hline & E & $2.15^{\mathrm{a}}$ & $3.37^{\mathrm{ab}}$ & $1.00^{\mathrm{ab}}$ & nd & nd & nd \\
\hline & F & $2.60^{\mathrm{ab}}$ & $3.79^{\mathrm{ab}}$ & $2.21^{\mathrm{bcd}}$ & 0.75 & nd & nd \\
\hline
\end{tabular}

${ }^{1}$ Mean values of four batches made with the A, B, C, D and E starters, or six batches of the F cheeses. $2 \mathrm{~A}=$ Lactococcus lactis ssp. lactis CCBA 201; B = Lactococcus lactis ssp. lactis CCBA 208; C = Lactococcus lactis ssp. lactis CCBA 311; D = Lactococcus lactis ssp. lactis CCBA 334; E = commercial starter; $\mathrm{F}=$ without starter. a, b, c, d: means of the same column with different superscripts differ significantly $(P<0.05)$. nd: not detected.

onwards, the counts evolved quite similarly in all types of cheeses, with the differences being small and not significant. The general trend for lactic acid bacteria was a gradual decline as ripening progressed, the final reduction being approximately $1-1.5$ logarithmic units.

The mean enterococci counts in all types of cheeses remained practically constant throughout ripening, although at the 
end of the ripening a very slight decrease could be observed. However, the counts in the commercial starter cheeses were in all cases significantly lower $(P<0.05)$ than for the other types at the same times of ripening.

Taking into account the resistance of enterococci to such adverse conditions as low $\mathrm{pH}$, drying and high salt levels [19], the inhibition of enterococci in commercial starter cheeses could only be due to the antimicrobial action of the bacteria which form that starter. Such antienterococcal action could be due to a bacteriocin, since, in the control cheeses made with the same raw milk but without starter, the enterococci counts were about $2.5 \mathrm{log}$ units higher than in the commercial starter cheeses. Similar observations have been made by Kandarakis et al. [10] and Ortigosa et al. [15], who also found levels of enterococci significantly lower in cheeses made with commercial starters as compared with cheeses made without starter. We agree with the opinion of different authors $[6,11$, 18] that enterococci can play a useful role during ripening in contributing beneficially to cheese characteristics. For this reason, it may not be desirable to inhibit this type of microorganism. The presumed inhibition of enterococci could be an example of the unpredictable effect that the use of commercial starters can have on the wild microflora of raw milk.

Maximum counts of coliforms were observed on the first day of ripening for all batches, the highest being, as we expected, those of cheeses manufactured without starter. Afterwards they declined rapidly in all types of cheeses, disappearing completely after $60 \mathrm{~d}$ in cheeses made with autochthonous starters, although they persisted at very low levels in batches made with commercial starter and without starter. The inhibition of coliform growth in all types of cheeses may mainly be due to the low $\mathrm{pHs}$ attained during ripening [4].

The counts of coagulase positive staphylococci were not very high in the milk, and were only slightly higher on the first day of ripening. Thereafter they decreased in all batches from day 7 onwards, and were not even detected at this stage in batches manufactured with starter A. After day 30, no coagulase positive staphylococci were detected in any of the batches manufactured with the different types of starters but they still remained in cheeses made without starter. At day 60 they were not found in any batch. The total inhibition of coagulase positive staphylococci during ripening, as has been reported for raw milk Ibores cheese [12], is a common occurrence in many types of cheeses [16, 17, 20]. It is generally due to low pHs [13], but the combined effect of other factors may also be involved [5].

\subsection{Sensorial evaluation}

The sensory assessment of the various completed batches is summarized in Table V.

The most favorable scores for texture and cut appearance were obtained for cheeses $\mathrm{C}$ and $\mathrm{D}$, and the lowest score for texture was obtained by cheeses of type A.

The highest scores for taste intensity were for cheeses made without starter (type F). These cheeses also showed the significantly highest values of TCASN/TN after 30, 60 and $75 \mathrm{~d}$ of ripening, and there was a significant correlation $(P<0.05)$ between taste intensity and levels of TCASN/TN at $75 \mathrm{~d}$. Similar findings have been made by Fernandez del Pozo et al. [3] and Litopoulou-Tzanetaki et al. [11].

For taste quality, batches manufactured with the B autochthonous starters received the best score. The highest scores for intensity and quality of aroma were for cheeses made with the D autochthonous starter. No significant correlations were detected between the intensity or quality of aroma and the physicochemical characteristics of any of the cheeses.

Considering the overall sensorial characteristics, the batches manufactured with 
Table V. Organoleptic characteristics at $75 \mathrm{~d}$ of ripening of Ibores cheeses made with different starters ${ }^{1}$.

\begin{tabular}{lllllll}
\hline Attribute & $\mathrm{A}^{2}$ & $\mathrm{~B}^{2}$ & $\mathrm{C}^{2}$ & $\mathrm{D}^{2}$ & $\mathrm{E}^{2}$ & $\mathrm{~F}^{2}$ \\
\hline Colour & $3.63^{\mathrm{a}}$ & $4.11^{\mathrm{c}}$ & $3.94^{\mathrm{abc}}$ & $4.03^{\mathrm{bc}}$ & $3.77^{\mathrm{ab}}$ & $3.83^{\mathrm{abc}}$ \\
Cut appearance & $3.47^{\mathrm{a}}$ & $3.73^{\mathrm{ab}}$ & $4.06^{\mathrm{b}}$ & $3.91^{\mathrm{b}}$ & $3.81^{\mathrm{ab}}$ & $3.43^{\mathrm{a}}$ \\
Texture & $2.83^{\mathrm{a}}$ & $3.25^{\mathrm{ab}}$ & $3.33^{\mathrm{b}}$ & $3.32^{\mathrm{b}}$ & $3.29^{\mathrm{b}}$ & $3.25^{\mathrm{ab}}$ \\
Taste intensity & $2.90^{\mathrm{a}}$ & $3.30^{\mathrm{ab}}$ & $3.11^{\mathrm{ab}}$ & $3.29^{\mathrm{ab}}$ & $3.29^{\mathrm{ab}}$ & $3.49^{\mathrm{b}}$ \\
Taste quality & $2.87^{\mathrm{ab}}$ & $3.30^{\mathrm{b}}$ & $2.78^{\mathrm{a}}$ & $3.14^{\mathrm{ab}}$ & $3.13^{\mathrm{ab}}$ & $3.08^{\mathrm{ab}}$ \\
Aroma intensity & $2.70^{\mathrm{a}}$ & $3.00^{\mathrm{ab}}$ & $2.78^{\mathrm{a}}$ & $3.23^{\mathrm{b}}$ & $2.84^{\mathrm{a}}$ & $3.07^{\mathrm{ab}}$ \\
Aroma quality & $2.86^{\mathrm{a}}$ & $3.19^{\mathrm{ab}}$ & $3.00^{\mathrm{ab}}$ & $3.37^{\mathrm{b}}$ & $2.87^{\mathrm{a}}$ & $3.20^{\mathrm{ab}}$ \\
General acceptance & $3.03^{\mathrm{a}}$ & $3.37^{\mathrm{b}}$ & $3.25^{\mathrm{ab}}$ & $3.44^{\mathrm{b}}$ & $3.27^{\mathrm{ab}}$ & $3.31^{\mathrm{b}}$ \\
\hline
\end{tabular}

${ }_{1}^{1}$ Mean values of four batches made with the A, B, C, D and E starters, or six batches of the F cheeses. $2 \mathrm{~A}=$ Lactococcus lactis $\mathrm{ssp}$. lactis CCBA 201; B = Lactococcus lactis ssp. lactis CCBA 208; C = Lactococcus lactis ssp. lactis CCBA 311; D = Lactococcus lactis ssp. lactis CCBA 334; $\mathrm{E}=$ commercial starter; $\mathrm{F}=$ without starter. $\mathrm{a}, \mathrm{b}, \mathrm{c}$ : means of the same row with different superscripts differ significantly $(P<0.05)$.

the autochthonous starter type A gave the least satisfactory results while types B and $\mathrm{D}$ were awarded the best scores, although the differences with cheeses manufactured without starter were not significant $(P>0.05)$.

\section{CONCLUSIONS}

The autochthonous starters in Ibores cheesemaking were successful at reducing the levels of coliforms and coagulase positive staphylococci earlier in ripening than in cheeses made without starter and even in those made with the commercial starter. Furthermore, they maintained levels of lactic acid bacteria, and physicochemical and sensorial characteristics very close to those of cheeses made without starter. Consequently the use of selected autochthonous starters would be desirable in order to improve the microbiological quality of Ibores cheese without significantly changing its typical properties, thereby avoiding the loss-of-individuality disadvantage of using commercial starters. Further attempts to develop new autochthonous starters for Ibores cheese by mixing strains are in our future research plans.

\section{ACKNOWLEDGEMENTS}

This work was supported by grants 1FD970216-C02 (FEDER Funds) and IPR00C002 (Junta de Extremadura). The authors are grateful to D. Valcárcel and A. Acedo for technical assistance.

\section{REFERENCES}

[1] Ardö Y., Evaluating proteolysis by analysing the $\mathrm{N}$ content of cheese fractions, Bull. Int. Dairy Fed. 337 (1999) 4-9.

[2] Church F.C., Swaisgood H.E., Portier D.H., Catignani G.L., Spectrophotometric assay using $o$-phthaldialdehyde for determination of proteolysis in milk and isolated milk proteins, J. Dairy Sci. 66 (1983) 1219-1227.

[3] Fernández del Pozo B., Gaya P., Medina M., Rodríguez-Marín M.A., Núñez M., Changes in chemical and rheological characteristics of La Serena ewes' milk cheese during ripening, J. Dairy Res. 55 (1988) 457-464.

[4] Gaya P., Medina M., Nuñez M., Accelerated decrease of Enterobacteriaceae counts during ripening of raw milk Manchego cheese by lactic culture inoculation, J. Food Protect. 46 (1983) 305-308.

[5] Gaya P., Medina M., Bautista L., Nuñez M., Influence of lactic starter inoculation, curd heating and ripening temperature on Staphylococcus aureus behaviour in Manchego cheese, Int. J. Food Microbiol. 6 (1988) 249-257. 
[6] Giraffa G., Enterococcal bacteriocins: their potential as anti-Listeria factors in dairy technology, Food Microbiol. 12 (1995) 291-299.

[7] IDF, Cheese and processed cheese products. Determination of the total solids content, Standard 4 A, Int. Dairy Fed., Brussels, Belgium, 1982.

[8] IDF, Cheese and processed cheese products. Determination of chloride content. Potentiometric titration method, Standard 88 A, Int. Dairy Fed., Brussels, Belgium, 1988.

[9] IDF, Guideline determination of acidifying activity of dairy cultures, Bull. Int. Dairy Fed. 306 (1995) 34-36.

[10] Kandarakis I.G., Moschopoulou E.E., Moatsou G.A., Anifantakis E.M., Effect of starters on gross and microbiological composition and organoleptic characteristics of Graviera Kritis cheese, Lait 78 (1998) 557-568.

[11] Litopoulou-Tzanetaki E., Tzanetakis N., Vafopoulou-Mastrojiannaki A., Effect of the type of lactic starter on microbiological composition and sensory characteristics of Feta cheese, Food Microbiol. 10 (1993) 31-41.

[12] Mas M., Tabla R., Moriche J., Roa I., González J., Rebollo J.E., Cáceres P., Ibores goat's milk cheese: Microbiological and physicochemical changes throughout ripening, Lait 82 (2002) 579-587.

[13] Nuñez M., Bautista L., Medina M., Gaya P., Staphylococcus aureus, thermostable nuclease and staphylococcal enterotoxins in raw ewes' milk Manchego cheese, J. Appl. Bacteriol. 65 (1988) 29-34.

[14] Olarte C., Sanz S., González-Fandos E., Torre P., The effect of a commercial starter culture addition on the ripening of an artisanal goat's cheese (Cameros cheese), J. Appl. Microbiol. 88 (2000) 421-429.

[15] Ortigosa M., Bárcenas P., Arizcun C., PérezElortondo F., Albisu M., Torre P., Influence of the starter culture on the microbiological and sensory characteristics of ewe's cheese, Food Microbiol. 16 (1999) 237-247.

[16] Poullet B., Huertas M., Sánchez A., Cáceres P., Larriba G., Microbial study of Casar de Cáceres cheese throughout ripening, J. Dairy Res. 58 (1991) 231-238.

[17] Sanchez-Rey R., Poullet B., Cáceres P., Larriba G., Microbial quality and incidence of some pathogenics microorganisms in $\mathrm{La}$ Serena cheese throughout ripening, J. Food Protect. 56 (1993) 879-881.

[18] Tzanetakis N., Vafopoulou-Mastrojiannaki A., Litopoulou-Tzanetaki E., The quality of white-brined cheese from goat's milk made with different starters, Food Microbiol. 12 (1995) 55-63.

[19] Vanos V., Importance of streptococci group $\mathrm{D}$ in fermented dairy products, as indicators of quality assurance in comparison with coliforms, Bull. Int. Dairy Fed. 264 (1991) 20-25.

[20] Zárate V., Belda F., Pérez C., Changes in the microbial flora of Tenerife goats' milk cheese during ripening, Int. Dairy J. 7 (1997) 635-641. 